\title{
Агробиологическая и технологическая характеристика технических сортов винограда из Дагестана
}

\author{
Батуч Мухтаровна Гусейнова ${ }^{1}$, д-р с.-х. наук, профессор кафедры товароведения, технологии продуктов и
} общественного питания, batuch@yandex.ru;

Фируза Алимирзаевна Ашурбекова ' ${ }^{1}$ соискатель ученой степени канд. с.-х. наук кафедры товароведения, технологии продуктов и общественного питания;

Татьяна Идрисовна Даудова ${ }^{2}$, ст. науч. сотр. лаборатории биохимии и биотехнологии

${ }^{1}$ Федеральное государственное бюджетное образовательное учреждение высшего образования «Дагестанский государственный аграрный университет имени М. М. Джамбулатова», Россия, Республика Дагестан, 367032, г. Махачкала, ул. М. Гаджиева, 180;

${ }^{2}$ Федеральное государственное бюджетное учреждение науки Прикаспийский институт биологических ресурсов ДНЦ РАН, Россия, Республика Дагестан, 367032, г. Махачкала, ул. М. Гаджиева, 45

\begin{abstract}
Определены агробиологические и технологические показатели винограда сортов Асыл кара, Платовский, Рубин Голодриги, Саперави и Алый терский с целью получения данных об адаптивных проявлениях интродуцентов к условиям культивирования в Дагестане, и определения сортов с лучшими технологическими свойствами. Исследования проводили с применением современных и классических методов агробиологического учета и определения технологических свойств винограда. Результаты фенологических наблюдений показали различия в наступлении периода полной зрелости ягод у исследованного винограда (от 1 до 43 дней), что говорит о влиянии экологических условий места выращивания и позволяет причислить сорта к следующим группам по срокам созревания: Платовский в Дагестане проявил свойства винограда сверхраннего срока созревания, Асыл кара - раннесреднего, Алый терский - среднего, а Саперави и Рубин Голодриги - среднепозднего. Урожайность винограда - главный показатель оценки степени адаптации сорта к условиям возделывания, у интродуцированных сортов Асыл кара и Рубин Голодриги высокая (70-100 ц/га), у Платовского, Саперави и аборигенного сорта Алого терского очень высокая (свыше 100 ц/га). Лучшими по строению грозди оказались сорта Саперави $(27,6)$ и Платовский $(24,6)$, высокое значение показателя её сложения определено у сортов Рубин Голодриги $(16,2)$, Алый терский $(13,9)$ и Саперави $(13,2)$. Последние лидировали и по величине структурного показателя (отличались большим количеством мякоти с соком - 88-91\% от массы грозди и низким содержание скелета и твердого остатка), что является ценным технологическим свойством, которое у интродуцентов Рубина Голодриги и Саперави проявилось также хорошо, как и у аборигенного сорта Алого терского. У всех изученных сортов содержание сахаров и титруемых кислот соответствовало требованиям, предъявляемым к техническим сортам. Сведения о положительном проявлении адаптивных способностей исследованных сортов в условиях южной равниннопредгорной зоны Дагестана важны на современном этапе формирования промышленного сортимента для успешного развития виноградовинодельческой отрасли сельского хозяйства Республики Дагестан.

Ключевые слова: виноград; интродуцированные сорта; агробиологические показатели; технологические признаки; почвенно-климатические условия Дагестана.
\end{abstract}

\section{O R I G I N A L RES EARCH Agrobiological and technological
characteristics of wine grapevine
cultivars from Dagestan}

Batuch Mukhtarovna Guseynova ${ }^{1}$, Firuza Alimirzayevna Ashurbekova ${ }^{1}$, Tatyana Idrisovna Daudova ${ }^{2}$

${ }^{1}$ Federal State Budgetary Educational Institution of Higher Education Dagestan State Agricultural University named after M.M. Dzhambulatov, 180 M. Gadzhieva street, 367032 Makhachkala, Republic of Dagestan;

${ }^{2}$ Prikaspiyskiy Institute of Biology Resources of Daghestan Science Centre of the Russian Academy of Sciences, 45 M. Gadzhieva street, 367025

Makhachkala, Republic of Dagestan

The agrobiological and technological characteristics of grapevine cultivars 'Asyl kara', 'Platovskiy', 'Rubin Golodrigi', 'Saperavi' and 'Alyi terskii' were assessed in order to collect data on adaptive behaviour of introduced species in the conditions of Dagestan, and determine cultivars with the best technological properties. Modern and standard methods were applied for agrobiologic registration and determination of technological properties of grapevines. The phenological observation data revealed differences in the full berry ripeness period of the studied cultivars (from 1 to 43 days) which confirms the ecological conditions impact of the cultivation place, and allows to rank cultivars by the following groups according to berry ripening dates: 'Platovskiy' in Dagestan demonstrated the potential of an extra early ripening period; 'Asyl kara' -early and medium, 'Alyi terskii' - medium, and 'Saperavi' and 'Rubin Golodrigi' - medium and late ripening period. Grapevine fertility is the principal indicator in assessment of the extent of grapevine adaptation to certain cultivation conditions. Thus, introduced cultivars 'Asyl kara' and 'Rubin Golodrigi' demonstrated high fertility (70100 c/ha), 'Platovskiy', 'Saperavi' and aboriginal variety 'Alyi terskii' - very high fertility (over $100 \mathrm{c} / \mathrm{ha}$ ). By cluster morphology, 'Saperavi' (27.6) and 'Platovskiy' (24.6) cultivars were the best. The high value of morphology indicator was demonstrated by 'Rubin Golodrigi' (16.2), 'Alyi terskii' (13.9) and 'Saperavi' (13.2). The latter were in the lead also by the structural indicator value (they stood out for a large amount of pulp with juice - 88-91\% of the cluster weight, and low crest weight and solid residue), which is a valuable technological characteristic demonstrated by 'Rubin Golodrigi', 'Saperavi', and aboriginal grapevine 'Alyi terskii'. Sugar and titratable acids content of all the studied cultivars were consistent with the requirements for wine cultivars. Data on positive manifestation of adaptive abilities of the studied cultivars in the conditions of the southern plain-piedmont zone of Dagestan are important for the formation of industrial assortment to ensure successful development of the viticinicultural industry of the agriculture of the Republic of Dagestan.

Key words: grapevines; introduced cultivars; agro-biological indicators; technological indicators; soil climatic conditions of Dagestan.

\section{Как цитировать эту статью:}

Гусейнова Б.М., Ашурбекова Ф.А., Даудова Т.И. Агробиологическая и технологическая характеристика технических сортов винограда из Дагестана // «Магарач». Виноградарство и виноделие, 2019; 21(3); C. 217-222. DOI 10.35547/IM.2019.21.3.006

\section{How to cite this article:}

Guseynova B.M., Ashurbekova F.A., Daudova T.I. Agrobiological and technological characteristics of wine grapevine cultivars from Dagestan. Magarach. Vinogradarstvo $i$ Vinodelie = Magarach. Viticulture and Winemaking, 2019; 21(3):217-222. DOI 10.35547/IM.2019.21.3.006 (in Russian) 
$\mathrm{O}$ собое место в Российской Федерации по производству винограда принадлежит Республике Аагестан, где виноградарство - одна из наиболее рентабельных отраслей сельского хозяйства. ПиощаАь виноградных насажАений на её территории в настоящее время превышает 22 тыс. га (примерно $27 \%$ от общей площади виноградных насаждений в РФ). Валовый сбор винограда в республике за период 2015-2018 гг. в среднем составим 167,9 тыс. т, а средняя урожайность виноградных насаждений - 98,6 ц/га.

ВинограА - это пластичное растение, активно откиикающееся на экологические особенности места культивирования. Изучение изменения агробиомогических показателей и технологических свойств технических сортов винограда, произрастающих в разАичных почвенно-кмиматических условиях, весьма актуацьно, так как известно, что виноградное растение может максимацьно реализовать свой биологический потенциал Аишь в определенном диапазоне изменения природных факторов. Кроме того, такие исследования необходимы Аця выявления среди интродуцированных сортов, наиболее аАаптированных к агроэкологическим условиям зоны виноградарства, в которую они были завезены и в настоящее время выращиваются [1-6]. Технологическая характеристика сортов винограда важна Аця опредемения направления их использования в виноградной отрасли сельского хозяйства, виноделии и при производстве продуктов питания функционацьной направленности.

Целью исследований явмянось изучение агробиомогических и технологических показателей технических сортов винограда, выращиваемых в экологических условиях равнинно-предгорной южной зоны Аагестана, Аця выявления их адаптивных способностей, определения среди них сортов с Аучшими технологическими свойствами, из которых возможно получение новых продуктов питания высокого качества.

Объектами исследований явАялись интродуцированные сорта винограда Асым кара (Asylkara), Пцатовский (Platovskiy), Рубин Голодриги (Rubin Golodrigi), Саперави (Saperavi) и аборигенный - Амый терский (Alyi terskii) возделываемые в Аагестане на опытных участках производственных насаждений ООО «АКК-СТ» и ООО «ВинограАарь-1», расположенных в Аербентском и Табасаранском районах. ИсслеАования проводили в 2016-2018 гг.

ООО «АКК-СТ» явцяется одним из ведущих производителей винограда в Аагестане. Общая площадь виноградных насаждений здесь составАяет 981 га.

КАимат на территории ООО «АКК-СТ» формируется поА влиянием Каспийского моря и цепи гор ГАавного Кавказского хребта, который закрывает доступ вцажным западным ветрам. Среднегодовая температура воздуха $12,7-13,5^{\circ} \mathrm{C}$. По данным Аербентской гиАрометеорологической станции, июАь и август явмяются наиболее теплыми месяцами со среднемесячной температурой 24,8 и $24,1^{\circ} \mathrm{C}$. Максимальная температура Аостигает $35,6-37,3^{\circ} \mathrm{C}$. Годовое количество выпавших осаАков на территории хозяйства в среднем колебалось от 350 до 362 мм. Почва опыт- ного участка, расположенного на винограднике ООО «АКК-СТ», светло-каштановая, среднесуглинистая с тяжелым механическим составом, объемный вес $1,6 \mathrm{r} / \mathrm{cm}^{3}$.

ООО «Виноградарь-1» расположено в Аолине реки Рубас, примерно в 30 кимометрах от Каспийского моря, немного южнее Аербента.

КАимат здесь умеренный, без резких колебаний температуры воздуха, с заметно выраженной континентацьностью. Среднегодовая температура варьировала в пределах 11,7-12, $4^{\circ} \mathrm{C}$. Максимацьная температура воздуха Аостигала $31,9-34,7^{\circ} \mathrm{C}$. По количеству осаАков территория хозяйства относится к зоне Аостаточного увцажнения - 360-382 мм за год. Почва на опытном участке каштановая, среднесуглинистая. Почвообразующие породы - делювиальные суглинки, без признаков засоменности.

Схема посадки виноградных растений - 3,0 х 1,5 м, количество учетных кустов - 60, высота штамба 80-90 см. Насаждения привитые. Формировка кустов - горизонтацьный Авусторонний кордон. Система ведения кустов - малая чашевидная форма, с использованием трехпроволочной вертикальной шпалеры. Нагрузка по всем сортам 45-50 глазков при Алине обрезки 4-5 глазков. Агротехника на опытных участках винограАников - общепринятая.

Определение агробиологических и технологических показателей исследованных сортов винограАа проводили по общепринятым методикам [7-10]. Цифровой материал обрабатывался методом дисперсионного анализа однофакторного опыта [11].

Результаты исскедований. Фенологические наблюАения за виноградным растением позволяют установить сроки появления у него определенных морфологических изменений, сгруппировать сорта по срокам созревания и правильно определить сортимент винограАа, соответствующий конкретным агроэкологическим условиям возделывания.

Исследованные сорта винограда отличались по Аатам наступления и продолжительностью фаз вегетации, хотя распускание глазков у всех сортов наблюАацось в третьей декаде апреля. Самое раннее распусканием глазков отмечено у сорта П атовский, а наибомее позднее у сортов Асыц кара и Саперави. Продолжительность периода от распускания глазков Ао цветения в зависимости от сорта - 38-45 Аней. Раньше всех начиналось цвктение и созревали ягоды у сорта Платовский (табл.1). Отличие в наступлении периоАа полной зрелости у сортов составимо 1-43 Аня, что можно объяснить как биологическими особенностями сортов, так и воздействием на них почвенно-кмиматических факторов в период прохождения фенофаз.

Условия культивирования исследованных сортов в равнинно-преАгорной зоне юга Аагестана повлияли на сроки созревания винограАа. Например, сорт Асыл кара может быть отнесен к группе раннесреднего срока созревания, Алый терский - среднего, а сорта Саперави и Рубин Голодриги - среАнепозАнего.

Важными показателями оценки воздействия факторов окружающей среды на виноградное растение явАяются его продуктивность, а также величина и 
качество урожая. В практике известны многочисленные факты, когда один и тот же сорт винограда, выращенный в неодинаковых агроэкологических условиях, Аает резко отмичающийся по этим показатецям урожай. Поэтому главным критерием научного обоснования эффективности выращивания винограда на конкретной территории, где возможна максимацьная реацизация потенциа а его продуктивности, явцяется соответствие почвенно-кмиматических условий места выращивания требованиям сорта.

В ходе агробиологического учета и наблюдений (табл. 2) опредемими, что выращиваемые в Аагестане сорта Асы кара, Алый терский, Пцатовский, Рубин Голодриги и Саперави, согласно классификации М. А. Аазаревского, относятся к группе сортов с большой массой грозАи (150-250 г). Сопоставитемьный анализ массы грозди винограда ряда сортов, культивируемых в Аругих регионах, показац, что экомогические усмовия Аагестана могут способствовать формированию большей массы грозАи. Пример - у хорошо изученных сортов Рубина Гомодриги и Саперави, выращиваемых на наших опытных участках, средняя масса грозди равнямась 186 и 156 г, а в иных экологических условиях они имели массу грозАи 161,4 и 98,0 г соответственно [12-14].

В зависимости от коэффициента плодоношения, сорта винограда по плодоносности побегов могут быть разАелены на следующие группы: сорта с очень высокой плодоносностью побега - коэффициент плодоношения 1,2 и выше; высокой - 1,1-0,9; среАней - 0,80,6 ; низкой - 0,5-0,3 и очень низкой 0,2 и ниже. Все изученные сорта винограда (за искиючением сорта Саперави) относятся к группе сортов с высокой плодоносностью побега - 0,9 (ААый терский) - 1,2 (Пкатовский).

По величине урожайности сорта винограда подраздемяются на группы: с очень высокой - свыше 100 ц/га; высо кой - 71-100 ц/га; среАней - 51-70 ц/га и ниже среАней - 31-50 ц/га. Урожайность в годы исследований у изучаемых сортов варьироваца в предемах 89-137 ц/га, что объясняется в бомьшей степени сортовыми особенностями. Урожайность у Асым кары и Рубина Гомодриги высокая (70-100 ц/га), а у остацьных сортов - очень высокая (свыше 100 ц/га). Полученные Аанные говорят о перспективности воздемывания интродуциро-
Таблица 1. Продолжительность фенологических фаз у исследованных сортов винограда, выращиваемых в Дагестане (средние данные за 20162018 гг.)

Table 1. Duration of the phenological phases of the studied grapevine cultivars grown in Dagestan (means for 2016-2018)

\begin{tabular}{|c|c|c|c|c|c|c|}
\hline \multirow{2}{*}{ Сорт } & \multicolumn{4}{|c|}{ Аата начама фенологических фаз } & \multicolumn{2}{|c|}{$\begin{array}{l}\text { От распускания } \\
\text { почек Ао полной } \\
\text { зремости }\end{array}$} \\
\hline & $\begin{array}{l}\text { распу- } \\
\text { скание } \\
\text { гмазков }\end{array}$ & цветения & $\begin{array}{l}\text { созрева- } \\
\text { ния ягоА }\end{array}$ & $\begin{array}{l}\text { полная } \\
\text { зремость } \\
\text { ягоА }\end{array}$ & $\begin{array}{l}\text { число } \\
\text { Аней }\end{array}$ & $\mathrm{CAT},{ }^{\circ} \mathrm{C}$ \\
\hline Асыц кара & 30.04 & 8.06 & 4.08 & 7.09 & 130 & 2890 \\
\hline Амый терский & 28.04 & 12.06 & 14.08 & 16.09 & 141 & 2960 \\
\hline Пкатовский & 25.04 & 2.06 & 8.07 & 11.08 & 108 & 2250 \\
\hline Рубин Голодриги & 27.04 & 11.06 & 17.08 & 24.09 & 150 & 3030 \\
\hline Саперави & 30.04 & 11.06 & 15.08 & 28.09 & 151 & 3023 \\
\hline
\end{tabular}

Таблица 2. Урожайность и продуктивность сортов винограда, культивируемых в условиях Дагестана (средние данные за 2016-2018 гг.) Table 2. Fertility and productivity of grapevine cultivars grown in Dagestan (means for 2016-2018)

\begin{tabular}{|c|c|c|c|c|c|c|}
\hline \multirow{2}{*}{ Сорт } & \multirow{2}{*}{$\begin{array}{l}\text { Коэф- } \\
\text { фициент } \\
\text { плодоно- } \\
\text { шения, К }\end{array}$} & \multirow{2}{*}{$\begin{array}{l}\text { Средняя } \\
\text { масса } \\
\text { грозАи, г }\end{array}$} & \multirow{2}{*}{$\begin{array}{l}\text { Коэф- } \\
\text { фициент } \\
\text { пмодонос- } \\
\text { ности, К } 2\end{array}$} & \multirow{2}{*}{$\begin{array}{l}\text { Пцодо- } \\
\text { носность } \\
\text { побега, г }\end{array}$} & \multicolumn{2}{|c|}{$\begin{array}{l}\text { Расчетная уро- } \\
\text { жайность }\end{array}$} \\
\hline & & & & & кг/куст & ц/га \\
\hline Асым кара & 1,0 & 232 & 1,5 & 232 & 4,2 & 93 \\
\hline Амый терский & 0,9 & 210 & 1,3 & 189 & 5,6 & 137 \\
\hline Пкатовский & 1,2 & 200 & 1,4 & 240 & 4,5 & 108 \\
\hline Рубин ГолоАриги & 1,1 & 186 & 1,6 & 204,6 & 3,7 & 89 \\
\hline Саперави & 0,8 & 156 & 1,4 & 124,8 & 4,4 & 102 \\
\hline $\mathrm{HCP}_{05}$ & 0,12 & 20,64 & 0,08 & 32,94 & 0,45 & 13,36 \\
\hline
\end{tabular}

ванных сортов Рубин Голодриги, Пцатовский, Асым кара и Саперави на винограАниках равнинно-предгорной зоны Аагестана.

Изучение механического состава важно Аля определения наиболее эффективного способа хозяйственного использования раз$\Lambda$ ичных сортов винограда. В пищевой промышиенности с учётом этих показателей Аается технологическая характеристика сортам и разрабатывается соответствующая сорту винограда технология его переработки [15-18].

Определяется весовое и числовое соотношение пластических и механических элементов грозди: гребня, кожицы, мякоти с соком и семян, которые морфологически и физиологически отличаются у разных сортов винограда, а также в пределах одного сорта в зависимости от степени его зрелости, почвенно-кАиматических условий места культивирования и агротехнологии возделывания. У сорта Саперави, например, в зависимости от района выращивания масса грозАи может колебаться от 112,7 Ао 168,8 г. В грозАи может быть 83-121 ягода с процентом кожицы 5,3-10,3\% [13, 15, 19].

Анациз данных механического состава показац (табц. 3), что большим количеством ягоА в грозАи характеризовацись сорта Рубин Голодриги (120) и Асым кара (113), меньшим - Ацый терский (72).

При переработке винограда большое внимание уделяется процентному содержанию гребней и ягод в грозАях. По Аанным авторов работы [14] его значение состав яяет 1,0-9,0\%. Содержание гребней считается низким при количестве менее $2 \%$ массы грозАи, среАним - 2-4\%, высоким - 4-6\% и очень высоким - свыше 6\%. Содержание гребней в грозАях исследованных сортов варьировало от 3,5 Ао 4,7\%. Высокое их содержание определено у сортов Рубин Голодри- 
Agrobiological and technological characteristics of wine grapevine cultivars from Dagestan.

ги, Алый терский и Асым кара, среднее - у сортов Саперави и Пкатовский.

Показатель строения - отношение массы ягоА К массе гребней, составцям 20,3 (Асыл кара) - 27,6 (Саперави). Чем он выше, тем кучше, с точки зрения использования винограда, построена гроздь. В нашем случае у сортов Саперави и Пцатовский этот показатель бым наибольшим.

При технологической оценке сортов винограАа большое значение имеет и показатель сложения грозди (отношение массы мякоти с соком к массе кожицы). Как видно из табл. 4, масса 100 ягод винограда в зависимости от сорта составмяла 139-279 г. Наибольшая масса 100 семян у сорта Алый терский, а наименьшая - у сорта Саперави. Большое количество семян в 100 ягодах бымо у сортов Алый терский и Рубин Голодриги. Соотношение кожицы, мякоти и семян в 100 г ягоА изученных сортов сильно варьирует: при массе мякоти с соком от 125,1 ао 251,1 г, масса семян составцяна 4,4-9,7, а масса кожицы 8,3-18,1 г. Высокие значения показатемя сложения грозАи определены у сортов Рубин Голодриги $(16,2)$, Алый терский $(13,9)$ и Саперави $(13,2)$.

Структура гроздей винограда характеризуется процентным количеством в них кожицы, семян, мякоти, скемета (гребни + кожица) и твердого остатка (скелет + семена). В гроздях исследованного винограАа величины этого показателей варьировали в зависимости от сорта (табл. 5). Все сорта отличались высоким содержанием мякоти с соком (88-91\% от массы грозАи), процент кожицы составцям 1,7 (Рубин ГолоАриги) - 5,3 (Саперави). Содержание скемета и твердого остатка было низким у сортов Рубин Голодриги и Алый терский, в ягодах которых содержанось значительное количество сочной мякоти. ЯгоАный показатель (количество ягод на 100 г грозди) варьирован в широких преде-

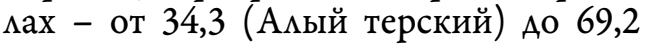
(Саперави). Самая большая величина структурного показателя грозди (отношение массы мякоти с соком к массе скемета грозди) была у интродуцированного сорта Рубин Голодриги. Аһя технических сортов это важно, так как чем выше значение структурного показателя, тем больше выхоА сока во время переработки винограда.

У всех сортов массовая концентрация сахаров и содержание титруемых кислот соответствоваца требованиям,
Guseynova B.M.,

Ashurbekova F.A., Daudova T.I.

VITICULTURE

Таблица 3. Строение грозди исследованных сортов винограда (средние данные за 2016-2018 гг.)

Table 3. Cluster morphology of the studied grapevine cultivars (means for 2016-2018)

\begin{tabular}{|c|c|c|c|c|c|}
\hline \multirow{2}{*}{ Сорт } & \multirow{2}{*}{$\begin{array}{l}\text { Масса гроз- } \\
\text { Аи, Г }\end{array}$} & \multirow{2}{*}{$\begin{array}{l}\text { Число ягоА в } \\
\text { грозАи, шт }\end{array}$} & \multicolumn{2}{|l|}{ Macca, $\%$} & \multirow{2}{*}{$\begin{array}{l}\text { Показате ь } \\
\text { строения }\end{array}$} \\
\hline & & & ягоА & гребней & \\
\hline Асым кара & 232 & 113 & 95,3 & 4,7 & 20,3 \\
\hline Амый терский & 210 & 72 & 95,7 & 4,3 & 22,2 \\
\hline Пиатовский & 200 & 100 & 96,1 & 3,9 & 24,6 \\
\hline Рубин ГолоАриги & 186 & 120 & 95,8 & 4,2 & 22,8 \\
\hline Саперави & 156 & 108 & 96,5 & 3,5 & 27,6 \\
\hline $\mathrm{HCP}_{05}$ & 20,6 & 13,2 & 0,33 & 0,32 & 2,08 \\
\hline
\end{tabular}

Таблица 4. Сортовые отличия сложения грозди опытных образцов винограда (средние данные за 2016-2018 гг.)

Table 4. Varietal differences in cluster composition of the trial grapevine samples (means for 2016-2018)

\begin{tabular}{|c|c|c|c|c|c|c|c|}
\hline \multirow[b]{2}{*}{ Сорт } & \multicolumn{2}{|c|}{ Macca, г } & \multirow{2}{*}{$\begin{array}{l}\text { Количество } \\
\text { семян в } 100 \\
\text { ягодах, шт }\end{array}$} & \multicolumn{3}{|c|}{ Масса в 100 ягодах, г } & \multirow{2}{*}{$\begin{array}{l}\text { Показатемь } \\
\text { сложения }\end{array}$} \\
\hline & $\begin{array}{l}100 \\
\text { ягоА }\end{array}$ & $\begin{array}{l}100 \\
\text { семян }\end{array}$ & & семян & кожицы & $\begin{array}{l}\text { мякоти с } \\
\text { соком }\end{array}$ & \\
\hline Асыл кара & 195 & 3,4 & 187 & 6,4 & 15,0 & 173,6 & 11,6 \\
\hline Амый терский & 279 & 4,6 & 210 & 9,7 & 18,1 & 251,1 & 13,9 \\
\hline Пматовский & 192 & 3,2 & 198 & 6,3 & 16,7 & 169,0 & 10,1 \\
\hline Рубин Гомодриги & 148 & 2,3 & 212 & 5,0 & 8,3 & 134,7 & 16,2 \\
\hline Саперави & 139 & 2,2 & 202 & 4,4 & 9,5 & 125,1 & 13,2 \\
\hline $\mathrm{HCP}_{05}$ & 37,7 & 0,71 & 7,44 & 1,4 & 3,7 & 33,3 & 1,72 \\
\hline
\end{tabular}

Таблица 5. Структурный состав виноградной грозди исследованных сортов (средние за 2016-2018 гг.)

Table 5. Cluster structural composition of the studied cultivars (means for 2016-2018)

\begin{tabular}{|c|c|c|c|c|c|c|c|}
\hline \multirow[b]{2}{*}{ Сорт } & \multicolumn{5}{|c|}{ \% от массы грозди } & \multirow{2}{*}{$\begin{array}{l}\text { ЯгоА- } \\
\text { ный } \\
\text { показа- } \\
\text { темь }\end{array}$} & \multirow{2}{*}{$\begin{array}{l}\text { Струк- } \\
\text { турный } \\
\text { показа- } \\
\text { темь }\end{array}$} \\
\hline & кожица & семена & $\begin{array}{l}\text { Мякоть } \\
\text { (с соком) }\end{array}$ & скемет & $\begin{array}{l}\text { твердый } \\
\text { остаток }\end{array}$ & & \\
\hline Асым кара & 3 & 3,3 & 89 & 7,7 & 11 & 48,7 & 11,6 \\
\hline Амый терский & 2,2 & 3,5 & 90 & 6,5 & 10 & 34,3 & 13,8 \\
\hline Пиатовский & 4,8 & 3,3 & 88 & 8,7 & 12 & 50,0 & 10,1 \\
\hline Рубин ГомоАриги & 1,7 & 3,1 & 91 & 5,9 & 9 & 64,5 & 15,4 \\
\hline Саперави & 5,3 & 3,2 & 88 & 8,8 & 12 & 69,2 & 10,0 \\
\hline $\mathrm{HCP}_{05}$ & 1,32 & 0,10 & 1,04 & 1,05 & 1,04 & 10,8 & 1,93 \\
\hline
\end{tabular}

преАъявцяемым к техническим сортам, предназначенным Амя выработки винодемьческой продукции (ГОСТ Р 53023-2008). Наиболее значительным сахаронакопмением отмичались сорта Платовский и Рубин Голодриги, в которых общее количество сахаров состав яло соответственно 19,8 и 21,4 г/100 см 3 . Аучшая титруемая кислотность быма в соке ягоА сортов Рубин Гомодриги - 8,3 и Амый терский 7,6 г/Ам³ ${ }^{3}$. Все исследованные сорта характеризовацись хорошими глюкоациАометрическими показателями - от 20,3 (ААый терский) Ао 25,0 (ПАатовский), что свидетельствует о гармоничном вкусе их ЯГОА.

Выводы. В результате проведенных фенологических наблюдений за развитием сортов Асыц кара, Ацый терский, Пцатовский, Рубин Гомодриги и Саперави, выращиваемых в почвенно-кмиматических условиях равнинно-предгорной виноградарской зоны на юге Аагестана, выявцены разАичия в наступцении срока полной зрецости их ягоА. Например, интродуцированный сорт Асым кара может быть отнесен к группе раннесреднего срока созревания, а интродуцированные Саперави и Рубин Голодриги - к сортам среднепозАнего периода созревания. 
Основной показатель оценки степени адаптации винограда к условиям природной зоны возделывания - вемичина и качество урожая. У интродуцированных сортов Асым кара и Рубин Голодриги он высокий (70100 ц/га), а у сортов Пцатовский, Саперави и аборигенного Ацый терский - очень высокий (свыше 100 ц/ га), что говорит о перспективности воздемывания всех исследованных сортов в почвенно-кмиматических усмовиях Аагестана.

Аучшее строение грозди имели интродуцированные сорта Саперави и Пцатовский. Высокие показатели структуры и сложения грозди были определены у сортов Рубин Гомодриги $(16,2)$, Алый терский $(13,9)$ и Саперави $(13,2)$, кроме того они имеми значитемьное количество мякоти с соком (88-91\% от массы грозди) и низкое содержание скелета и твердого остатка. Такие технологические свойства винограда обеспечивают обимьный выход сока во время его переработки, кроме того было определено, что у всех изученных сортов содержание сахаров и титруемых кислот в соке ягод соответствовацо требованиям, предъявцяемым к техническим сортам. Агробиологическая и технологическая характеристика интродуцированных сортов Асым кара, Пцатовский, Рубин Гомодриги, Саперави и аборигенного сорта Ацый терский свидетельствуют об их ценности Аһя использования в винодеАии и производстве продуктов питания с применением винограАного сырья. СвеАения о положительном проявцении аАаптивных способностей исследованных сортов в условиях южной равнинно-предгорной зоны важны на современном этапе формирования промышленного сортимента Аля успешного развития виноградовинодемьческой отрасли семьского хозяйства Респубцики Аагестан.

\section{Источники финансирования}

Не указаны.

\section{Financing source}

Not specified.

\section{Конфликт интересов}

Авторы статьи подтверАими отсутствие конфмикта интересов, о котором необходимо сообщить.

\section{Conflict of interest}

The authors confirmed the absence of conflict of interest, which must be reported.

\section{Список литературы/References}

1. Anderson, M.M., R.J. Smith, M.A. Williams, and J.A. Wolpert. Viticultural evaluation of French and California Pinot noir clones grown for production of sparkling wine. // Am. J. Enol. Vitic. - 2008. - No. 59. - P. 188-193.

2. Mercado-Martín, G.I., J.A. Wolpert, and R.J. Smith. Viticultural evaluation of eleven clones and two field selections of Pinot noir grown for production of sparkling wine in Los Carneros, California. // Am. J. Enol. Vitic. - 2006. - No. 57. - P. 371-376.

3. Mc Manus J.P., Davis K.G., Beart J.E. et al. Polyphenol interactions. Part Introduction: some observations on the reversible complexation of polyphenols with proteins and polysaccharides // J. Chem. Soc. Perkin Trans II 1985.- Vol. 2. - P.1429-1438.

4. Абрамов Ш. А., Власова О. К., Магомедова Е. С. Биохимические и технологические основы качества винограда. - Махачкала: ДНЦ РАН, 2004. - 343 с.
Гусейнова Б.М.,

Ашурбекова Ф.А., Ааудова Т.И.
[Abramov Sh. A., Vlasova O. K., Magomedova E. S. Biohimicheskie $i$ tekhnologicheskie osnovy kachestva vinograda [Biochemical and technological bases of quality of grapes]. - Makhachkala: DSC RAS, 2004. - 343 p. (in Russian)]

5. Даудова Т. И., Гусейнова Б. М. Химический состав сорта Молдова в зависимости от экологических условий места выращивания //Виноделие и виноградарство. - 2010. №6. - C.36-38.

[Daudova T. I., Guseynova B. M. Himicheskij sostav sorta Moldova $v$ zavisimosti ot ekologicheskih uslovij mesta vyrashchivaniya [The chemical composition of a grade Moldova depending on ecological conditions of the place of cultivation]. Vinodelie i vinogradarstvo [Winemaking and viticulture]. - 2010. - No. 6. - pp. 36-38. (in Russian)]

6. Наумова Л.Г., Ганич В.А. Перспективные аборигенные Дагестанские сорта винограда для возделывания в условиях Нижнего Придонья // Плодоводство и виноградарство Юга России. - 2016. - № 40(04). - С.30-38.

[Naumova L.G., Ganiç V. A. Perspektivnye aborigennye Dagestanskie sorta vinograda dlya vozdelyvaniya $v$ usloviyah Nizhnego Pridon'ya [Perspective native Dagestan grades of grapes for cultivation in the conditions of the Lower Don region]. Fruit growing and viticulture of South Russia [Plodovodstvo i vinogradarstvo YUga Rossii]. - 2016. - No. 40(04). - pp. 30-38. (in Russian)]

7. Лазаревский М.А. Изучение сортов винограда. - Ростовна-Дону: Издательство университета, 1963. - 151 с.

[Lazarevsky M.A. Izuchenie sortov vinograda [Studying of grades of grapes]. - Rostov-na-Donu: Izdatel'stvo universiteta, 1963. - 151p. (in Russian)]

8. Амирджанов А.Г., Сулейманов Д. С. Оценка продуктивности сортов винограда и виноградников: методические указания. - Баку, 1986. -56 с.

[Amirdzhanov A.G., Suleymanov D.S. Ocenka produktivnosti sortov vinograda $i$ vinogradnikov: metodicheskie ukazaniya [Assessment of efficiency of grades of grapes and vineyards: methodical instructions]. - Baku, 1986. -56 p. (in Russian)]

9. Простосердов Н.И., Охременко Н. С., Голодрига П.Я. Изучение винограда для определения его использования (увология). - М.: Пищепромиздат, 1963. - 79 с.

[Prostoserdov N.I., Okhremenko N.S., Golodriga P.Ya. Izuchenie vinograda dlya opredeleniya ego ispol'zovaniya (uvologiya) [Studying of grapes for definition of its using (uvologiya)]. M.: Pishchepromizdat, 1963. - 79 p. (in Russian)]

10. Codes des caracteres descritifs des varieties et especes de Vitis. - OIV. 2009. Website http://www.oiv. Int/fr/ и http:// www.oiv.int/oiv/info/frplubicationoiv\#listdesc.

11. Доспехов Б. А. Методика полевого опыта (с основами статистической обработки результатов исследований). М.: Альянс, 2014. - 351с.

[Dospekhov B.A. Metodika polevogo opyta (s osnovami statisticheskoj obrabotki rezul'tatov issledovanij) [A technique of field experiment (with bases of statistical processing of results of researches)]. - M.: Alliance, 2014. - 351 p. (in Russian)]

12. Игнатов А. П. Плодоношение и продуктивность сорта Рубин Голодриги в зависимости от длины обрезки побегов винограда // «Магарач» Виноградарство и виноделие. - 2011. - №2. C.10-11.

[Ignatov A. P. Plodonoshenie i produktivnost' sorta Rubin Golodrigi v zavisimosti ot dliny obrezki pobegov vinograda [Fructification and efficiency of a grade Rubin Golodrigi depending on length of cutting of escapes of grapes]. Magarach. Vinogradarstvo $i$ vinodelie [Magarach. Viticulture and winemaking]. - 2011. - No. 2. - pp.10-11. (in Russian)] 
13. Кравченко Р. В., Радчевский П. П., Прах А. В. Продуктивность винограда технического сорта Саперави на фоне применения лигногуматов марки «А» // Политематический сетевой электронный научный журнал КубГАУ. 2013. - № 92(08). - C. 642-651.

[Kravchenko R. V., Radchevsky P. P., Prah A.V. Produktivnost' vinograda tekhnicheskogo sorta Saperavi na fone primeneniya lignogumatov marki «A» [Productivity of grapes of a technical grade Saperavi against the background of application of lignogumat of brand "A"]. Polythematic network online scientific magazine of KUBGAU [Politematicheskij setevoj elektronnyj nauchnyj zhurnal KubGAU]. - 2013. - No. 92(08). - pp. 642-651. (in Russian)]

14. Негруль А. М., Гордеева Л. Н., Калмыкова Т. И. Ампелография с основами виноградарства. М.: Высшая школа, 1979. - 396 c.

[Negrul A. M., Gordeeva L. N., Kalmykova T. I. Ampelografiya s osnovami vinogradarstva [Ampelografiya with wine growing bases]. - M.: Vysshaya shkola, 1979. - 396 p. (in Russian)]

15. Чаусов В. М., Бурлаков М. М., Родионова Л. Я. и др. Механический состав гроздей и биохимия черноягодных винных сортов винограда для производства сока прямого отжима // Политематический сетевой электронный научный журнал КубГАУ. - 2016. - №118(04). - С. 147-163.

[Chausov V. M., Burlakov M. M., Rodionova L. Ya., et al. Mekhanicheskij sostav grozdej i biohimiya chernoyagodnyh vinnyh sortov vinograda dlya proizvodstva soka pryamogo otzhima [Mechanical structure of clusters and biochemistry the chernoyagodnykh of wine grades of grapes for production of juice of a direct extraction]. Politematicheskij setevoj elektronnyj nauchnyj zhurnal KubGAU [Polythematic network online scientific magazine of KUBGAU.] 2016. - No. 118(04). - pp. 147-163. (in Russian)]

16. Митракова С. И., Трошин Л. П., Радчевский П. П. Комплексно-устойчивые сорта-интродуценты винограда для производства натурального осветленного пастеризован- ного сока // Политематический сетевой электронный научный журнал КубГАУ. - 2012. - №78(04). - С. 574-587.

[Mitrakova S.I., Troshin L. P., Radchevsky P. P. Kompleksnoustojchivye sorta-introducenty vinograda dlya proizvodstva natural'nogo osvetlennogo pasterizovannogo soka [Complex and steady grades introduced species of grapes for production of the natural clarified pasteurized juice]. Politematicheskij setevoj elektronnyj nauchnyj zhurnal KubGAU [Polythematic network online scientific magazine of KUBGAU]. - 2012. No. 78(04). - pp. 574-587. (in Russian)]

17. Даудова Т.И., Магомедов Г.Г., Гусейнова Б.М. Механические свойства винограда, культивируемого в зоне Дагестанского Прикаспия // Известия Самарского научного центра РАН. - 2012. - Т. 14. - № 1-9. - С. 2211-2214.

[Daudova T.I., Magomedov G. G., Guseynova B.M. Mekhanicheskie svojstva vinograda, kul'tiviruemogo $v$ zone Dagestanskogo Prikaspiya [Mechanical properties of the grapes cultivated in the Dagestan Prikaspiya]. News of the Samara scientific center RAS [Izvestiya Samarskogo nauchnogo centra RAN]. - 2012. - Vol.14. - No. 1-9. - pp. 2211-2214. (in Russian)]

18. Даудова Т.И., Мукаилов М.Д., Гусейнова Б.М. и др. Транспортабельность столовых сортов винограда из Дагестана //Проблемы развития АПК региона. - 2018. - № 3 (35). - C. 151-155.

[Daudova T.I., Mukailov M.D., Guseynova B.M., et al. Transportabel'nost' stolovyh sortov vinograda iz Dagestana [Transportability of table grades of grapes from Dagestan]. Problems of development of agrarian and industrial complex of the region [Problemy razvitiya APK regiona]. - 2018. - No. 3 (35). - pp. 151-155. (in Russian)]

19. Ампелография СССР. Отечественные сорта винограда. М.: Легкая и пищевая промышленность, 1984. - 503с.

[Ampelografiya SSSR. Otechestvennye sorta vinograda [Ampelografiya of the USSR. Domestic grades of grapes]. - M.: Legkaya i pishchevaya promyshlennost', 1984. - 503 p. (in Russian)] 